\section{Pertumbuhan Bobot Hidup Burung Puyuh Jepang (Coturnix japonica L.) Setelah Diberi Ramuan Herbal}

\author{
Hasan Basri \\ Meilinda Pahriana Sulastri
}

\begin{abstract}
Abstrak. Penelitian ini merupakan penelitian eksperimental dengan Rancangan Acak Lengkap (RAL). Penentuan hewan uji pada setiap perlakuan secara random. Hewan uji menggunakan 24 puyuh Jepang yang diambil secara acak dari 42 puyuh berumur12 hari dan berat badan rerata $\pm 37.67 \mathrm{~g}$ dibagi dalam 4 kelompok perlakuan. Setiap perlakuan terdiri dari 6 ulangan. P0: kontrol; P1: perlakuan dengan pemberian herbal $3 \mathrm{ml}$ per 1 liter air bersih; P2: perlakuan dengan pemberian ramuan herbal $6 \mathrm{ml}$ per 1 liter air bersih; P3: perlakuan dengan pemberian ramuan herbal $9 \mathrm{ml}$ per 1 liter air bersih. Variable yang dianalisis meliputi bobot hidup per sepuluh hari. Data yang diperoleh dianalisis dengan varian (ANOVA), jika ada beda nyata dilanjutkan uji Duncan pada taraf signifikansi 95\%. Analisis dengan software SPSS 25. Berdasarkan hasil penelitian, pemberian ramuan herbal pada penelitian ini tidak berpotensi meningkatkan pertumbuhan puyuh.

Kata kunci: puyuh, ramuan herbal, bobot hidup
\end{abstract}

\section{Pendahuluan}

Burung puyuh (Coturnix japonica) merupakan salah satu jenis unggas yang memiliki pontensi untuk dikembangkan lebih lanjut sebagai alternatif sumber protein hewani yang murah dan mudah pemeliharaannya. Puyuh Jepang (Coturnix japonica L.) menjadi salah satu sektor peternakan yang efisien dalam menyediakan protein hewani berkualitas, baik berasal dari telur atau daging (Handarini dkk., 2008). Telur puyuh mengandung vitamin A sebesar $543 \mu \mathrm{g}$ (per 100g), omega-30,44\%, omega-6 1,62\%, Ca (51.89 mg/100gr), Fe (2.65 mg/100gr), Cu (0.104 mg/kg) dan $\mathrm{Zn}(1.04 \mathrm{mg} / \mathrm{kg}$ ) (Suripta et al., 2006; Dudusola, 2010; Basri, 2018). Keuntungan lain pemeliharan burung puyuh yang tidak membutuhkan modal besar, jika dibandingkan dengan pemeliharan komuditas unggas lainnya, karena siklus hidupnya pendek, tidak membutuhkan lahanyang luas, serta umur 40-45 hari sudah mulai bertelur. Usaha peternakan burung puyuh saat ini masih belum dikembangkan secara lebih intensif dibandingkan unggas-unggas yang lain. Postur tubuh burung puyuh yang kecil, dibutuhkan puyuh dalam jumlah besar untuk mendukung pasokan daging nasional. Perkembangan burung puyuh tidak secepat ayam broiler dan ayam petelur. Burung puyuh betina digunakan sebagai puyuh petelur sedangkan jantan dan yang sudah tua dipelihara untuk tujuan sebagai penghasil daging. Peran manajemen yang lebih modern, bisnis ternak burung puyuh sangat menjanjikan. Namun selain memiliki kelebihan ternyata ternak puyuh memiliki beberapa kekurangan yaitu sangat rentan terserang penyakit dan kondisi iklim di Indonesia

\section{BIONATURE}

p-ISSN 1411 - 4720

e-ISSN 2654 - 5160

Abstract. This study is experimental study with completely randomized design (CRD). Determination of the test animals for each treatment is randomly selected. The test animals used were 24 Japanese quail, taken randomly from 42 quails with the age of 12 days and average body weight of $\pm 37.67 \mathrm{~g}$ that divided into 4 treatment groups. Each treatment group consisted of 6 replications. P0: control; P1: given $3 \mathrm{ml}$ of herbal concoction per 1 liter of water; P2: given $6 \mathrm{ml}$ of herbal concoction per 1 liter of water; $P 3$ : given $9 \mathrm{ml}$ of herbal ingredients per 1 liter of water. The variables analyzed were live weight per ten days. The data obtained were analyzed with variance (ANOVA), if there is a significant difference, continue with Duncan's test at the 95\% significance level. Data analysis using SPSS 25 software. Based on the results of the study, the addition of herbal concoction in this study did not have the potential to increase the growth of quail.

Keywords: quail, herbal ingredients, live weight

Hasan Basri

Universitas Islam Al-Azhar

Indonesia

Meilinda Pahriana Sulastri Universitas Islam Al-Azhar Indonesia 
yang merupakan daerah tropis menyebabkan ternak mengalami cekaman stress suhu setiap saat. Akibatnya cekaman panas/hujan akan mengganggu produktivitas burung puyuh sehingga harus ditangani dengan serius, agar tidak memberikan pengaruh negatif (Listiyowati dan Roospitasari 2004). Beberapa upaya dalam meningkatkan produktivitas pada burung puyuh diberi perlakuan subterapik atau pemberian antibiotik. Penggunaan antibiotik yang terus menerus dengan dosis kurang tepat akan menimbulkan resistensi. Selain itu bakteri yang ada dalam saluran pencernaan dapat ikut terbunuh akibat spektrum kerja antibiotik yang luas. Lebih lanjut residu yang tersisa pada produk bahan pangan asal ternak yang dikonsumsi juga dapat menimbulkan dampak negatif terhadap kesehatan masyarakat. Upaya dalam menyelesaikan permasalahan tersebut perlu ada solusi yang kongkrit dalam menyelesaikannya. Salah satu upaya yang dilakukan yaitu memberikan pakan tambahan (feed additive) berupa ramuan herbal untuk meningkatkan nafsu makan dan ketahanan tubuh terhadap serangan penyakit pada burung puyuh (Poultry Indonesia, 2016; Andari dkk., 2018).

Menurut Hernani dan Marwati (2012) dan Badan Litbang Pertanian, (2013) yang dimaksud dengan ramuan herbal adalah ramuan yang berasal dari tumbuh-tumbuhan, hewan, mineral atau campuran dari bahan-bahan tersebut yang belum mempunyai data klinis, dan dipergunakan dalam pengobatan berdasarkan pengalaman. Menurut Zurahmah (2000) dan Agustina et al., (2017) bahan yang digunakan untuk pembuatan ramuan herbal dalam bentuk segar maupun kering disebut simplisia, seperti rimpang akar, daun, batang, dan buah. Bahan-bahan yang digunakan dalam penelitian ini seperti: kunyit, temu lawak, jahe, daun sirih, bawang putih, kayu manis, gula merah, EM4 dan air bersih. Penelitian tentang pemanfaatan ramuan herbal pada ternak unggas telah banyak dilakukan, di antaranya penggunaan kunyit, daun sirih dan jahe terhadap status profil lipid pada ayam pedaging dalam kondisi fisiologis normal (Basri dan Swandayani, 2019). Menurut Andari dkk., (2018) menyatakan suplementasi "Jamu Rempah" meningkatkan produktivitas puyuh. Berdasarkan uraian tersebut dilakukan pengujian ramuan herbal sebagai feed additive terhadap bobot hidup burung puyuh Jepang (Coturnix japonica L.).

\section{Metode Penelitian}

\section{Waktu dan Tempat Penelitian}

Penelitian ini dilakukan di Laboraturium Fakultas MIPA Universitas Islam Al-Azhar Mataram.

\section{Pembuatan Ramuan Herbal}

Proses pembuatan ramuan herbal, semua bahan ramuan herbal ditimbang dengan jumlah takaran yang sudah ditentukan. Komposisi dan satuan ramuan herbal di antaranya: Kunyit 250 g; Temu lawak 400 g; Jahe 250 g; Daun sirih 250 g; Daun pepaya 250 g; Bawang putih; Kayu manis 250 g; gula merah $500 \mathrm{~g}$ dan EM4. Semua bahan dicuci bersih dan diiris tipis. Selanjutnya diblender sampai halus dan diencerkan menggunakan 10 liter air hangat, kemudian diaduk sampai rata dan disaring, disimpan selama 7 hari untuk proses fermentasi. Ramuan herbal siap diberikan pada burung puyuh.

\section{Fumigasi}

Fumigasi dilakukan pada kandang, lantai, tempat pakan dan tempat minum dengan tujuan untuk sterilisasi. Desinfektan yang digunakan berupa Incunnol dan Yurisol. Incunnol digunakan untuk steriliasasi kandang. Larutan incunnol dibuat dengan melarutkan $20 \mathrm{ml}$ incunnol ke dalam $500 \mathrm{ml}$ air. Larutan incunnol tersebut disemprotkan pada seluruh bagian kandang, tempat pakan dan tempat minum. Kandang, tempat pakan dan tempat minum yang sudah disemprot larutan incunnol ditutup menggunakan koran untuk memaksimalkan hasil fumigasi selama 6 hari. 


\section{Aklimasi Puyuh}

Aklimasi dilakukan selama 6 hari. Puyuh Jepang dimasukkan pada kandang kolektif dengan formasi 15 ekor perkandang. Larutan gula dengan konsentrasi 1 sendok makan dalam 1liter air diberikan untuk memulihkan kondisi puyuh Jepang.

\section{Rancangan Penelitian}

Penelitian ini merupakan penelitian eksperimental dengan Rancangan Acak Lengkap (RAL). Penentuan hewan uji pada setiap perlakuan secara random. Hewan uji yang digunakan pada penelitian ini adalah puyuh jepang (Coturnix japonica L.) 24 ekor yang diambil secara acak dari 42 ekor puyuh jepang dengan umur mulai perlakuan 12 hari dan berat badan rerata \pm 37.67 g. Puyuh jepang yang sudah diambil tersebut dibagai dalam 4 kelompok perlakuan. Masin-masing kelompok perlakuan terdiri dari 6 ulangan. P0: sebagai kelompok perlakuan control; P1: kelompok perlakuan yang diberi ramuan herbal $3 \mathrm{ml}$ per 1 liter air bersih; P2: kelompok perlakuan yang diberi ramuan herbal $6 \mathrm{ml}$ per 1 liter air bersih; P3: kelompok perlakuan yang diberi ramuan herbal $9 \mathrm{ml}$ per 1 liter air bersih. Variable yang dianalisis meliputi bobot hidup persepuluh hari.

\section{Pengukuran bobot puyuh Jepang}

Pengukuran bobot puyuh Jepang ditimbang menggunakan timbangan digital

\section{Analisis Data}

Data yang diperoleh dianalisis dengan varian (ANOVA), jika ada beda nyata dilanjutkan uji Duncan pada taraf signifikansi 95\%. Analisis dengan perangkat software SPSS 25 for windows.

\section{Hasil Dan Pembahasan}

Hasil analisis statistik pemberian ramuan heral terhadap bobot hidup burung puyuh Jepang (Coturnix japonica L.) tersaji pada Tabel 1.

\section{Tabel 1. Hasil Analisis Statistik Pemberian Ramuan Herbal Terhadap Bobot Hidup Burung Puyuh Jepang (Coturnix japonica L.)}

\begin{tabular}{|c|c|c|c|c|}
\hline \multirow{2}{*}{ Variabel } & \multicolumn{4}{|c|}{ Perlakuan } \\
\cline { 2 - 5 } & P0 & P1 & P2 & P3 \\
\hline 10 hari pertama & $50.00 \pm 6.32$ & $48.33 \pm 7.53$ & $46.67 \pm 8.16$ & $43.33 \pm 8.16$ \\
\hline 10 hari ke-dua & $91.66 \pm 11.69$ & $98.33 \pm 14.72$ & $90.00 \pm 10.95$ & $86.67 \pm 17.51$ \\
\hline 10 hari ke-tiga & $128.33 \pm 13.29$ & $143.33 \pm 25.03$ & $145.00 \pm 13.78$ & $136.67 \pm 19.66$ \\
\hline 10 hari ke-empat & $195.00 \pm 15.16$ & $195.00 \pm 20.74$ & $196.67 \pm 13.66$ & $191.67 \pm 36.56$ \\
\hline
\end{tabular}

Keterangan: angka yang diikuti dengan superscript yang sama dalam baris yang sama menunjukan tidak berbeda nyata $(\mathrm{P}>0,05)$. P0: sebagai kelompok perlakuan control; P1: kelompok perlakuan yang diberi ramuan herbal $3 \mathrm{ml}$ per 1 liter air minum; P2: kelompok perlakuan yang diberi ramuan herbal $6 \mathrm{ml}$ per 1 liter air minum; P3: kelompok perlakuan yang diberi ramuan herbal $9 \mathrm{ml}$ per 1 liter air minum.

Berdasarkan hasil analisis statistik bobot badan 10 hari pertama menunjukkan hasil tidak berbeda nyata $(\mathrm{P}>0,05)$ baik terdapat pada perlakuan $\mathrm{P} 0$ : control dengan memperoleh bobot badan $50.00 \pm 6.32(\mathrm{~g}), \mathrm{P} 1$ : diberi ramuan herbal $3 \mathrm{ml}$ per 1 liter air, dengan memperoleh bobot 
badan $48.33 \pm 7.53(\mathrm{~g})$, P2: diberi ramuan herbal $6 \mathrm{ml}$ per 1 liter air dengan memperleh bobot badan $46.67 \pm 8.16$ (g) dan P3: diberi ramuan herbal 9 ml per 1 liter air dengan memperoleh bobot badan $43.33 \pm 8.16(\mathrm{~g})$.

Berdasarkan hasil analisis 10 hari minggu ke-dua menunjukkan hasil tidak berbeda nyata $(\mathrm{P}>0,05)$, baik terdapat pada perlakuan P0, P1, P2, dan P3. Rerata kenaikan bobot badan setiap perlakuan dari 10 minggu pertama ke 10 hari minggu ke dua sebesar P0: $41.66(\mathrm{~g}), \mathrm{P} 1: 50.00 \mathrm{(g})$, P2: 44.67 (g), P3: 43.34 (g). Perlakuan P1 dengan pemberian ramuan herbal 3 ml per 1 liter air minum cendrung lebih tinggi dibanding dengan perlakuan control sebesar 50.00 (g). Untuk mendapatkan kenaikan bobot badan rerata dari tiap perlakuan dengan cara: bobot badan minggu ke-dua dikuarangi bobot badan minggu pertama.

Berdasarkan hasil analisis statistik 10 hari minggu ke-3 menunjukkan hasil tidak berbeda nyata $(\mathrm{P}>0,05)$, baik terdapat pada perlakuan P0, P1, P2, dan P3. Rerata kenaikan bobot badan setiap perlakuan dari 10 hari minggu ke-2 ke 10 hari minggu ke-3 sebesar P0: 36.67 (g), P1: 45.00 (g), P2: 55.00 (g), P3: 50.00 (g). Perlakuan P2 dengan pemberian ramuan herbal 6 ml per 1 liter air minum cendrung lebih tinggi dibanding dengan perlakuan control sebesar $55.00(\mathrm{~g})$.

Berdasarkan hasil analisis statistik 10 hari minggu ke-4 menunjukan hasil yang tidak berbeda nyata $(\mathrm{P}>0,05)$, baik terdapat pada perlakuan P0, P1, P2 dan P3. Rerata kenaikan bobot badan pada setiap perlakuan dari 10 hari minggu ke-3 sebesar P0: 66.67 (g), P1: 51.67 (g), P2: 51.67 (g), P3: 55 (g). Pemberian ramuan herbal pada semua perlakuan terhadap bobot hidup burung puyuh tidak berpengaruh nyata kemungkinan disebabkan oleh tidak ada perbedaan pada konsumsi pakan yang diberikan dan lingkungan. Hal ini sesuai dengan pendapat Kartadisastra (1997) menyatakan bahwa bobot tubuh ternak senantiasa berbanding lurus dengan konsumsi ransum, makin tinggi bobot tubuhnya, makin tinggi pula konsumsinya terhadap ransum. Hal ini sesuai dengan penelitian yang menunjukkan bahwa tidak adanya perbedaan konsumsi pakan maka bobot badan tidak berbeda. Factor lingkungan diantaranya berupa kelembaban dan suhu. Hasil pengamatan terhadap kelembaban dan suhu lingkungan dengan rata-rata adalah $60-80 \%$ dan $22-29^{\circ} \mathrm{C}$. Suprijatna dkk (2005) menyatakan bahwa ternak unggas mampu berproduksi stabil pada kisaran kelembaban $30-80 \%$ dan temperatur $10-30^{\circ} \mathrm{C}$.

Pertumbuhan burung puyuh merupakan salah satu proses baku dalam kehidupan. Secara sederhana proses pertumbuhan burung puyuh dapat didefinisikan sebagai proses pertambahan massa dan selalu diikuti dengan proses perkembangan. Bobot tubuh merupakan akumulasi hasil metabolisme. Hasil metabolisme didukung oleh banyaknya pakan yang dikonsumsi serta optimalisasi penggunaan pakan. Efisiensi penggunaan energi ditentukan oleh faktor-faktor seperti ketersediaan bahan makanan, nutrisi, genetik, dan faktor-faktor hormon yang mempengaruhi kebutuhan energi tersedia terhadap produksi energi (Djulardi dkk, 2006).

\section{Kesimpulan}

Berdasarkan hasil penelitian dapat disimpulkan bahwa, pemberian ramuan herbal pada penelitian ini tidak berpotensi untuk meningkatkan pertumbuhan bobot badan puyuh Jepang (Coturnix japonica L.).

\section{Referensi}

Andari, A. Anisa, E.N., Wulandari, R.F \& Suci, D.M. (2018). Efek suplementasi “Jamu Rempah" pada puyuh (Coturnix coturnix japonica) terhadap performa dan kadar kolesterol telur. Jurnal Ilmu Nutrisi dan Teknologi Pakan. 16 (2), 34-41.

Badan Litbang Pertanian. (2013). Tanaman obat, warisan tradisi nusantara untuk kesejahteraan rakyat. Kementerian Pertanian. Jakarta. 108 hal. 
Basri, H., Saraswati, T.R., Isdadiyanto, S. (2018). Hematological status of rats (Rattus norvegicus L) in the lactation period after giving supplements organic quail egg. International Journal of Biological Research. 6 (1),1-4

Basri, H \& Swandayani, R.E. (2019). Pemberian Formula Pakan Herbal Terhadap Profil Lipid Pada Ayam Pedaging. Media Bina Ilmiah. 13(12), 1847- 1854

Djulardi, A., Helmi, M., Suslina, A.L. (2006). Nutrisi Aneka Ternak Dan Satwa Harapan. Andalas University Press. Padang.

Dudusola I.O. (2010). Comparative Evaluation of Internal and External Qualities of Eggsfrom Quail and Guinea Fowl. Int. Res. J. Plant Sci. 1,112-115.

Hernani dan Marwati. (2012). Teknologi pascapanen tanaman obat. Balai Besar Penelitian dan Pengembangan Pascapanen Pertanian. Badan Penelitian dan Pengembangan Pertanian. Bogor. 50 hal.

Kartadisastra, H.R. (1997). Penyediaan dan pengelolaan Pakan Ternak Ruminansia. Kanisius. Jakarta.

Listiyowati E, Roospitasari K. (2004). Puyuh Tata Laksana Budidaya Secara Komersial. Penebar Swadaya. Jakarta.

Poultry Indonesia. (2016). Mengenal jenis-jenis imbuhan pakan. Jakarta, 34 hal.

Suripta, H \& Astuti. P. 2016. The Effects of Sardine and Palm Oil in Rations on the Rasio of Omega3 to Omega-6 Fatty Acids in Eggs of Coturnix coturnix japonica. J. Indon. Trop. Anim. Agric. 32(1), 22-27

Suprijatna, E., Umiyati, A \& Ruhyat, K. (2005). Ilmu Dasar Ternak Unggas. Penebar Swadaya. Jakarta

Zurahmah, N. (2000). Manfaat fitobiotik untuk ternak unggas. Makalah ilmu nutrisi ternak lanjut. Universitas Gadjah Mada Yogjakarta. 25 hal

\begin{tabular}{|l|l|}
\hline Hasan Basri & $\begin{array}{l}\text { Dosen Pendidikan Biologi, Fakultas Matematika dan Ilmu } \\
\text { Pengetahuan Alam, Universitas Islam Al-Azhar, Mataram - } \\
\text { NTB } \\
\text { E-mail: } \underline{\text { hasanbasri7491@gmail.com }}\end{array}$ \\
\hline Meilinda Pahriana Sulastri & $\begin{array}{l}\text { Dosen, Pendidikan Biologi, Fakultas Matematika dan Ilmu } \\
\text { Pengetahuan Alam, Universitas Universitas Islam Al-Azhar, } \\
\text { Mataram - NTB } \\
\text { E-mail: } \underline{\text { indapahri@gmail.com }}\end{array}$ \\
\hline
\end{tabular}

